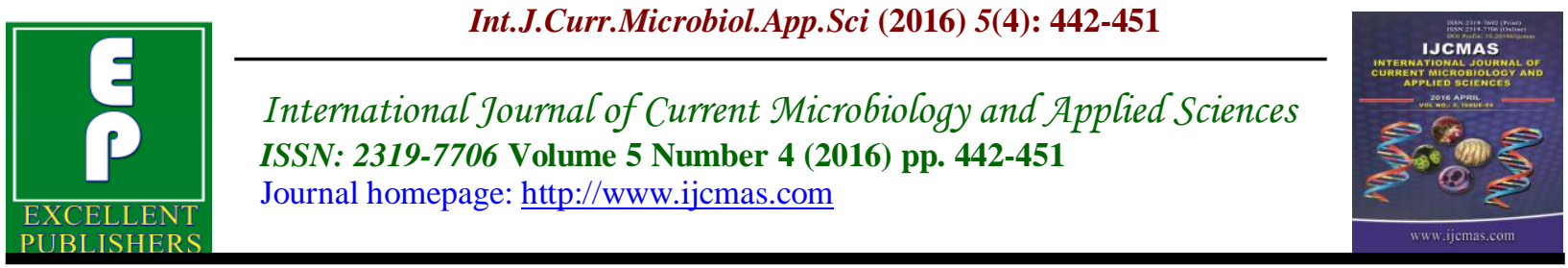

Original Research Article

http://dx.doi.org/10.20546/ijcmas.2016.504.052

\title{
Isolation, Screening, Identification and Optimized Production of Extracellular Cellulase from Bacillus subtilis Sub.sps using Cellulosic Waste as Carbon Source
}

\author{
K.Venkateswar Reddy ${ }^{1 *}$, T.Vijaya Lakshmi ${ }^{1}$, A.Vamshi Krishna Reddy ${ }^{1}$, \\ V. Hima Bindu ${ }^{1}$ and M.Lakshmi Narasu ${ }^{2}$ \\ ${ }^{1}$ Center for Environment, Institute of Science and Technology, JNTUH, Kukatpally, Hyderabad- \\ 500085, Telangana, India \\ ${ }^{2}$ Center for Biotechnology, Institute of Science and Technology, JNTUH, Kukatpally, \\ Hyderabad-500085, Telangana, India \\ *Corresponding author
}

\begin{tabular}{|c|c|}
\hline & A B S T R A C T \\
\hline Keywords & \multirow{4}{*}{$\begin{array}{l}\text { The bioconversion of cellulose is important for global stabilization and a suitable } \\
\text { human society. In this study, efficient cellulolytic bacteria were screened and } \\
\text { isolated from paper industry effluent contaminated soil. Among the isolates, three } \\
\text { strains showing higher potential for cellulase production were purified and sub } \\
\text { cultured on carboxy methyl cellulose (CMC) agar plates. Among the three strains, } \\
\text { one strain was given maximum enzyme activity. The isolate were identified as } \\
\text { Bacillus subtilis sub.sps by morphological, physiological, biological and } 16 \mathrm{~S} \text { rRNA } \\
\text { gene sequence analysis. The isolated strain produced cellulase enzyme complex, } \\
\text { with suggested synergic cellulolytic systems in Bacillus subtilis sub.sps. Cellulase } \\
\text { was produced in cellulase enzyme production media containing waste paper as } \\
\text { carbon source and the culture conditions like temperature, } \mathrm{p}^{\mathrm{H}} \text {, incubation time and } \\
\text { medium components and nitrogen sources were optimized. Optimal concentration } \\
\text { of inoculum for enzyme production is } 2 \% \text { and incubation time is } 60 \mathrm{hrs.} \mathrm{Optimum} \\
\text { temperature and pH of the medium for the cellulase production by Bacillus subtilis } \\
\text { sub.sps was } 45^{\circ} \mathrm{C} \text { and } \mathrm{pH} 6-7 \text {. }\end{array}$} \\
\hline $\begin{array}{l}\text { Cellulolytic } \\
\text { bacteria, } \\
\text { molecular } \\
\text { identification, } \\
16 \text { S rRNA, } \\
\text { Bacillus subtilis } \\
\text { sub.sps, cellulase. }\end{array}$ & \\
\hline Article Info & \\
\hline $\begin{array}{l}\text { Accepted: } \\
\text { 20 March } 2016 \\
\text { Available Online: } \\
10 \text { April } 2016\end{array}$ & \\
\hline
\end{tabular}

\section{Introduction}

Lignocellulosic materials are the most economic and highly renewable natural resources in the world (Zhu et al., 2006), lignocelluloses materials contain sugar and polymerized to cellulose and hemicellulose that can be liberated by hydrolysis and subsequently fermented by microorganisms to form different chemicals (Beak et al., 2007). It has become considerable economic interest to develop processes for effective treatment and utilization of cellulose waste as inexpensive carbon sources. Cellulases provide a key opportunity for achieving tremendous benefits of biomass utilization. Enzymes are delicate protein molecules necessary for life. Cellulose is the most abundant biomass on the earth. (Venkata et al., 2013). Plant biomass contains cellulose as the major components. Cellulase is the 
enzyme that hydrolyzes the $\beta-1,4$ glycosidic bonds in the polymer to release glucose units. Cellulase is a multi enzyme system composed of several enzymes with numerase isozymes which act in synergy. Cellulases (3.2.1.4) have wide range of industrial applications such as textile, laundry, pulp and paper, fruit juice extraction and animal feed additives as well as in bioethanol production. (Bhat.,2000). The cellulases have great potential in saccharification of lignocellulosic to fermentable sugars which can be used for production of bioethanol, lactic acid and single cell protein. (Maki et al., 2009). Cellulases are widely spreads in nature, predominantly produced by microorganisms like molds, fungi and bacteria (Perez et al., 1999). There has been increasing interest in cellulase production by bacteria because of fast growth rate (Petre et al., 1999). Some bacterial species viz., Cellulomonas species, Pseudomonas species, Bacillus species and Micrococcus have cellulolytic property (Nakamura and Kappamura, 1982). A large number of microorganisms are capable of degrading cellulose only a few of them produces significant quantity of cell free bioactive compounds capable of completely hydrolyzing crystalline cellulose in vitro.

The objective of our study was to isolate identify and characterize those isolates displaying the greatest cellulase activity and optimize the cellulase production using $\mathrm{CMC}$ and waste paper as carbon source for the possible use in large scale biorefining.

\section{Materials and Methods}

\section{Isolation and Screening of Cellulolytic Microbes}

Soil contaminated with paper industry effluents was collected from A.P. Paper Mills Limited, located in Rajahmundry, East
Godavari District of Andhra Pradesh, India. This soil sample were serially diluted and spread plated on a CMC agar. The plates were incubated for $2-3$ days at $37^{\circ} \mathrm{C}$ and observed for clear zone around the colony. To visualize the hydrolysis zone the plates were flooded with an aqueous solution of $0.1 \%$ Congo red for $15 \mathrm{~min}$. (Brandner et al., 1999). To visualize clear zone formed by cellulase positive strains the plates were destained using $1 \mathrm{M} \mathrm{NaCl}$ solution. Positive and better zone producing strain was choosen and used for further studies. Positive colony from these CMC agar plates were sub cultured on fresh CMC plate. These plates were used as master plate.

\section{Identification of Bacteria}

For the identification of strain of interest cultural characteristics, morphological characteristics and biochemical tests were conducted and identified on the basis of characters as given in Bergey's manual of systematic Bacteriology (Bergey, 1957). The parameters investigated included Indole test, Methyl red test, Voges Proskauer test, Citrate utilization test, Catalase test, Oxidase test, Gelatin test, Motility test, Amylase test, Nitrate reduction test, Carbohydrate fermentation test by standard methods. The various media was prepared in sterile distilled water and $\mathrm{pH}$ was adjusted accordingly.

\section{Molecular Identification of Bacterial Isolates}

DNA was extracted and purified by using a Qiagen genomic DNA extraction kit. The complete length of the $16 \mathrm{~S}$ rRNA gene sequence was obtained by sequencing with primers, F'-27 (5'-GTTTGATCCTGGC TCAG-3'), and R'-1489 (5'-TACCTTGTT ACGACTTCA-3') (Positions 11-27 and 1489-1506 (for F'-27 and R'-1489 
respectively). 16S rRNA gene sequencing was performed on a 3130xl Applied Biosystems ABI prism automated DNA sequencer.16S rRNA gene sequences of both the strains were identified by BLAST search analysis on EzTaxon-e server (Kim et al., 2012).

\section{Cellulase Enzyme Production Medium}

The carboxy methyl cellulose (CMC) broth containing $0.2 \% \mathrm{w} / \mathrm{v} \mathrm{CMC}$ and paper waste as sole carbon energy source was used for the enzyme production $2 \%$ of bacterial culture was inoculated into $50 \mathrm{ml}$ of the sterile CMC broth. The cultures were incubated in shaking for 3days at $37^{\circ} \mathrm{C}$. Cultures were harvested by centrifugation at $6000 \times \mathrm{g}$ for 15 minutes and the cell free culture supernatant used as crude enzyme source.

The cellulase activity of each culture was measured by determining the amount of reducing sugars liberated by using a dinitrosalicyclic acid (DNS) method (Miller, 1959), one unit of FPase, and CMCase activity was defined as the amount of enzyme which released in $\mu$ mole of reducing sugar measured as glucose per minute under the assay conditions.

\section{CMCase Assay}

CMCase activity was measured using a reaction mixture containing $1 \mathrm{ml}$ of $1 \%$ carboxymethyl cellulose in $0.5 \mathrm{M}$ sodium phosphate buffer at $\mathrm{pH}(6.0)$ with $0.5 \mathrm{ml}$ of enzyme supernatant filtrate (Wood, 1988). The reaction mixture was incubated at $50^{\circ} \mathrm{C}$ for 30 minutes and the reducing sugar produced was determined by DNS method. Total protein and sugar were also estimated according to Miller (Miller, 1959) and Lowry's method (Huang, 1971).

\section{Filter Paper Assay}

Filter paper assay (FPase) for total cellulase activity in the culture filtrate was determined according to the standard method $0.5 \mathrm{ml}$ of culture filtrate as enzyme source was added to whatmann No.1filter paper strip $(1 \times 6 \mathrm{~cm}$, $50 \mathrm{mg}$ ) immersed in $1 \mathrm{ml}$ of $0.5 \mathrm{M}$ sodium phosphate buffer of $\mathrm{pH}$ 6.0. After incubation at $50^{\circ} \mathrm{C}$ for 30 minutes the reducing sugar release was estimated by dinitrosalicyclic acid (DNS) method (Ghose, 1987) one unit of filter paper (FPU) activity was defined as the amount of enzyme releasing $1 \mu$ mole of reducing sugar from filter paper per $\mathrm{ml}$ per minute.

\section{Optimization of Production Parameters}

The various process parameters that influence the enzyme production were optimized over a wide range process parameters such as incubation period, initial $\mathrm{pH}$, incubation temperature, different nitrogen sources and inoculum size were optimized for maximum enzyme production in triplicates. The most suitable $\mathrm{pH}$ of the fermentation medium was determined by adjusting the $\mathrm{pH}$ of the culture medium at different levels in the range of $\mathrm{pH}$ 3.0-9.0. In order to determine the effective temperature for cellulase production, fermentation was carried out at different temperature in the range of 20 to $50^{\circ} \mathrm{C}$.

The fermentation was carried out up to $120 \mathrm{hrs}$ and the production rate measured at $12 \mathrm{hrs}$ intervals. To detect the appropriate nitrogen source for cellulase production by the isolate the fermentation medium was supplemented with yeast extract, peptone and malt extract nitrogen compound at $0.5 \%$ level there by substituting the prescribed nitrogen source of the fermentation medium. 


\section{Results and Discussion}

\section{Isolation and Screening of the Cellulase Producing Bacteria}

Bacteria are well known agents of decomposition of organic matter in general and of cellulosic substrate in particular as reported by (Lynd et al., 2002). As bacteria can utilize wide range of cellulosic waste, therefore interest in the search for cellulase producing novel bacterial species is increasing. The present study was carried out with an aim of isolating, screening and identification of efficient cellulase producing bacteria from paper industry effluent contaminated soil.

Paper and pulp effluent containing samples are rich with cellulosic substrates are the best sources in which we can isolate cellulolytic micro organisms. These effluent samples rich source of diverse group of cellulolytic micro organisms. Further its wide availability, ease of processing and cost effectiveness also plays an important role for its selection. The cellulase producing bacteria were isolated from different samples by serial dilution method and spread plating on CMC agar. The isolates were named as Bacillus subtilis subspecies and Bacillus cereus. CMC agar is a selective media and selectively supports the growth of the cellulolytic organisms because cellulase producing organisms can only utilize cellulose as the carbon source.

The screening of the cellulolytic bacterial isolates was performed based on the diameter of clearing zone around the colony on the $\mathrm{CMC}$ agar medium. The appearance of clearing zone around the colony after the addition of congored solution was strong evidence that the bacteria produced cellulase in order to degrade cellulose. The diameter of clearing zone for each isolate is shown table 1. There are around 10 bacterial cultures were grown on CMC agar. Among the 10 isolates depending on the diameter of clear zone around the colony two bacterial strains were identified as efficient cellulase producing bacteria and the isolate Bacillus subtilis subspecies has given highest clear zone diameter and its initial identification was done by gram staining, colony morphology and molecular identification based on 16s rRNA gene sequences. The remaining isolate has given clear zone less than $25 \mathrm{~mm}$. So that they are eliminated from this study. The isolate Bacillus subtilis subspecies has been used for further studies in the enzyme production and their ability to degrade cellulose.

\section{Morphological and Biochemical Characteristics of Bacillus subtilis Subspecies}

The isolate Bacillus subtilis sub species purified by repeated sub culturing on the nutrient agar medium at regular intervals and stored at $4^{\circ} \mathrm{C}$. The isolates were identified based on the morphological and biochemical characteristics (Table 2). The morphology of isolate is milk creamy white, flat rough colonies with irregular edges, motile and spreading rapidly on the surface of agar medium. They are gram positive bacilli in singles with spares centrally positioned. The isolate is oxidase positive, glucose fermenting (with acetone and gas). Sucrose fermenting and are indole and methyl red negative, voges proskauer, citrate, Catalase, gelatin, amylase and nitrate reduction test are positive. Which are the characteristics biochemical properties of Bacillus subtilis sub sps.

\section{Molecular Characterization based on 16S rRNA Gene}

The GenBank/EMBL/DDBJ accession numbers for the 16S rRNA gene sequences of strains are RW\& JCEN1.HG421740\&HF 951564 respectively. 
DNA was extracted and purified by using a Qiagen genomic DNA extraction kit. The complete length of the $16 \mathrm{~S}$ rRNA gene sequence was obtained by sequencing with primers, F'-27 (5'-GTTTGATCCTGG CTCAG-3'), and R'-1489 (5'-TACCTT GTTACGACTTCA-3') (Positions 11-27 and 1489-1506 (for F'-27 and R'-1489 respectively). 16S rRNA gene sequencing was performed on a 3130xl Applied Biosystems ABI prism automated DNA sequencer.16S rRNA gene sequences of both the strains were identified by BLAST search analysis on EzTaxon-e server (Kim et al., 2012). Strain.RW was sequence similarity with Bacillus cereus (98.47\%), and strain JCEN1 was sequence similarity with Bacillus subtilis (99.6\%)

\section{Cellulase Enzyme Production and Assay}

Cellulases production was quantitatively determined for isolates grown in the CMC and paper waste as substrate as shown in table 3. The FPase and CMCase activities of Bacillus subtilis subspecies was higher than other isolates, suggesting that these isolate which have appreciable cellulolytic activity as valuable in the bioconversion process of cellulolytic materials.

\section{Optimization of Cellulase Enzyme Production}

\section{Effect of Incubation Period on Cellulase Production}

The incubation period for enzyme production by Bacillu subtilis is detected in the production medium which contains paper waste as carbon source from the first day to fifth day. The maximum production was found between 48 to 72 hours and the major peak activity was found at $60 \mathrm{hrs}$ (Bacillus subtilis $0.98 \pm 0.02$ ). Incubation beyond the optimum time showed rapid decline in the enzyme yields at 96hrs. It might be due to the depletion of nutrients in the medium which stressed the bacterial physiology resulting in the inactivation of secretary machinery of the enzymes (Araffin, 2004) most of the Bacillus species are maintaining log phase from 3 to $12 \mathrm{hrs}$ of its growth. This variation of log phase timing is based on the nutrients present in the medium and the cultural condition of the organism (Yang et al., 1995).

\section{Effect of Temperature on Cellulase Production}

Temperature is also an important factor that influence the cellulase yield maximum enzyme production by Bacillus subtilis was found at $45^{\circ} \mathrm{C}$. The maximum cellulase production was obtained at temperature $45^{\circ} \mathrm{C}(0.941 \pm 0.02 \mathrm{U} / \mathrm{ml})$. Many workers have reported different temperatures for maximum cellulase production either in flask (or) in fermenter studies using Bacillus species suggesting that the optimal temperature. For cellulase production depends on the strain variation of the microorganisms. (Immanuel et al., 2006). The maximum endo glucanase activity was recorded in Cellulomonas, Bacillus and Micrococcus species at $40^{\circ} \mathrm{C}$ at neutral $\mathrm{pH}$.

\section{Effect of pH on Cellulase production}

Cellulase production at $45^{\circ} \mathrm{C}$ under various $\mathrm{pH}$ was shown in figure 3 . Hydrogen ion concentration of the production medium strongly affects many enzymatic processes and transport of compounds across the cell membrane. The optimum $\mathrm{pH}$ for maximum enzyme production was 7 followed by 6 . Enzyme activity gradually increased when increasing the $\mathrm{pH}$ up to the optimum followed by a gradual fall in activity. Most micro organisms grow optimally within a wide $\mathrm{pH}$ range, (Immanuel et al., 2006) 
reported that the cellulolytic enzyme endoglucanase from cellulomonas, Bacillus and micrococcus species isolated from the estuarine coir retting effluents hydrolyzes substrates in the $\mathrm{pH}$ range of 4.0 to 9.0 with maximum activity at $\mathrm{pH} 7.0$ contrary to that, (Song et al., 1985) observed optimal cellulase production at $\mathrm{pH} 9.0$ by clostridium acetobutylicum.

\section{Effect of Inoculum Concentration on Cellulase Production}

The effect of concentration of inoculum on enzyme production was studied by inoculating different concentration of inoculums ranges from $1 \%$ to $3 \%$ in $\mathrm{CMC}$ broth. The concentration of initial inoculums plays a critical role in enzyme yield in production media. The media was inoculated with different concentration of inoculums and incubated at $45^{\circ} \mathrm{C}$ for $72 \mathrm{hrs}$. The optimum enzyme production observed in inoculums concentration ranges from $1.5 \%$ to $2.5 \%$ of inoculums (fig 4 ). The maximum production obtained in $2 \%(0.887 \pm$ $0.02 \mathrm{U} / \mathrm{ml})$ followed by 2.5 and $1.5 \%(0.43 \pm$ $0.02 \mathrm{U} / \mathrm{ml})$

Table. 1 The Zone of Clearance of Cellulase Enzyme Produced by Bacterial Isolates Isolated from Paper Industry Effluent Contaminated Soil

\begin{tabular}{|c|c|c|}
\hline Isolates & Organism & Diameter of clear zone (mm) \\
\hline Isolate I & Bacillus subtilis subspecies & 28 \\
\hline Isolate II & Bacillus cereus & 24 \\
\hline
\end{tabular}

Table.2 Staining and Biochemical Characteristics of the Bacterial Isolate Bacillus subtilis Subspecies

\begin{tabular}{lll}
\hline S.No & $\begin{array}{l}\text { Morphological and } \\
\text { Biochemical tests }\end{array}$ & Result \\
\hline $\mathbf{1 .}$ & Gram staining & Gram positive \\
$\mathbf{2 .}$ & Endospore staining & Positive \\
$\mathbf{3 .}$ & Motility test & Positive \\
$\mathbf{4 .}$ & Indole test & Negative \\
$\mathbf{5 .}$ & Methyl red test & Negative \\
$\mathbf{6 .}$ & Voges proskauer test & Positive \\
$\mathbf{7 .}$ & Citrate utilization test & Positive \\
$\mathbf{8 .}$ & Catalase test & Positive \\
$\mathbf{9 .}$ & Oxidase test & Positive \\
$\mathbf{1 0 .}$ & Gelatin test & Positive \\
$\mathbf{1 1 .}$ & Amylase test & Positive \\
$\mathbf{1 2 .}$ & Nitrate reduction test & Positive \\
$\mathbf{1 3 .}$ & Carbohydrate & \\
& fermentation test & \\
& a) Glucose & Positive \\
& b) Lactose & Negative \\
& c) Sucrose & Positive \\
& d)Mannitol & Negative \\
\hline
\end{tabular}


Table.3 Production of Cellulase by Bacterial Isolates in Media with CMC as Carbon Source

\begin{tabular}{|l|c|c|c|c|}
\hline Isolates & CMCase (U/ml) & FPase (U/ml) & Protein $\mathbf{~ m g / m l ) ~}$ & Sugar (mg/ml) \\
\hline Isolate I Bacillus subtilis & 1.00 & 0.89 & 3.33 & 0.555 \\
\hline Isolate II Bacillus cereus & 0.70 & 0.79 & 2.85 & 0.345 \\
\hline
\end{tabular}

Table.4 Production of Cellulase by Bacterial Isolates in Media with Paper

Waste as Carbon Source

\begin{tabular}{|l|c|c|c|c|}
\hline Isolates & CMCase (U/ml) & FPase (U/ml) & Protein mg/ml) & Sugar (mg/ml) \\
\hline Isolate I Bacillus subtilis & 1.11 & 0.99 & 3.59 & 0.598 \\
\hline Isolate II Bacillus cereus & 0.75 & 0.89 & 3.15 & 0.385 \\
\hline
\end{tabular}

Figure.1 Effect of Incubation Time on Enzyme Production by Bacillus subtilis in Enzyme

Production Media Containing Waste Paper as Carbon Source

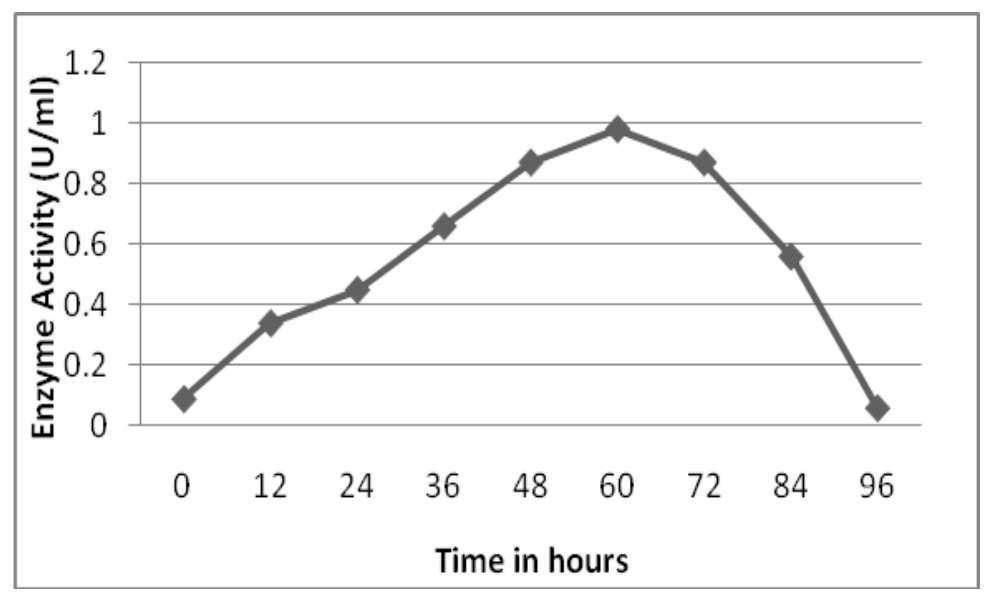

Figure.2 Effect of Temperature on Enzyme Production by Bacillus subtilis in Enzyme Production Media Containing Waste Paper as a Carbons Source

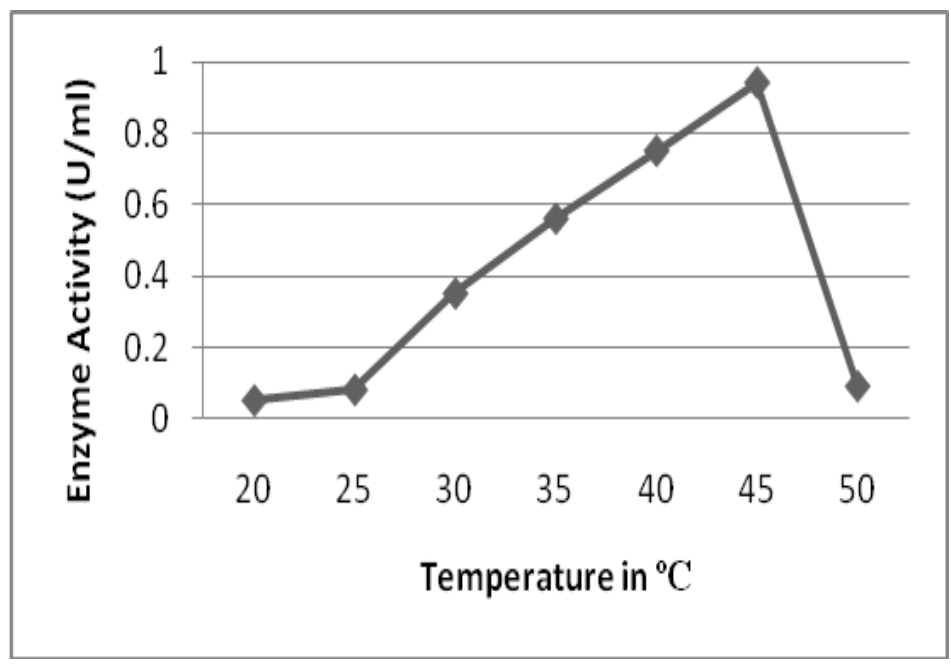


Figure.3 Effect of Ph on Enzyme Production by Bacillus subtilis in Enzyme Production Media Containing Waste Paper as Carbon Source

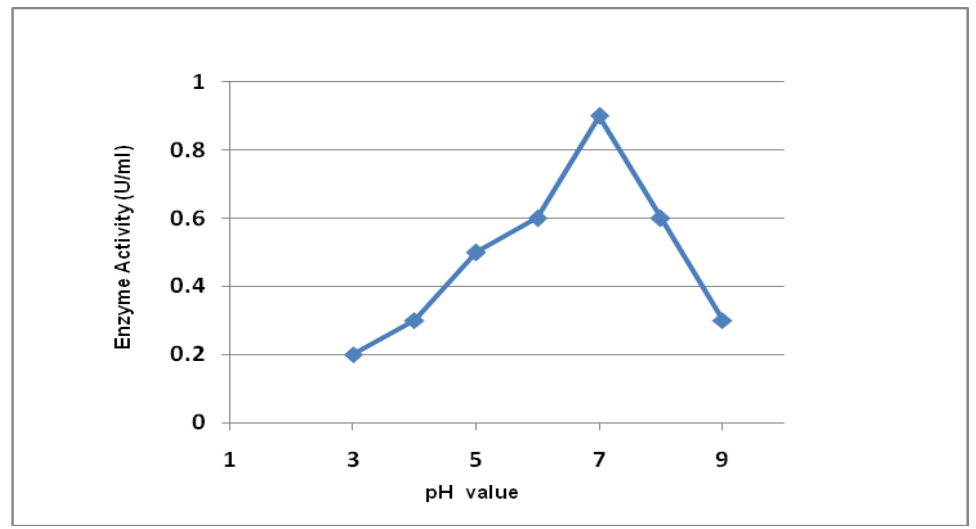

Figure.4 Effect of Inoculums Concentration on Enzyme Production by Bacillus subtilis in Enzyme Production Media Containing Waste Paper as Carbon Source

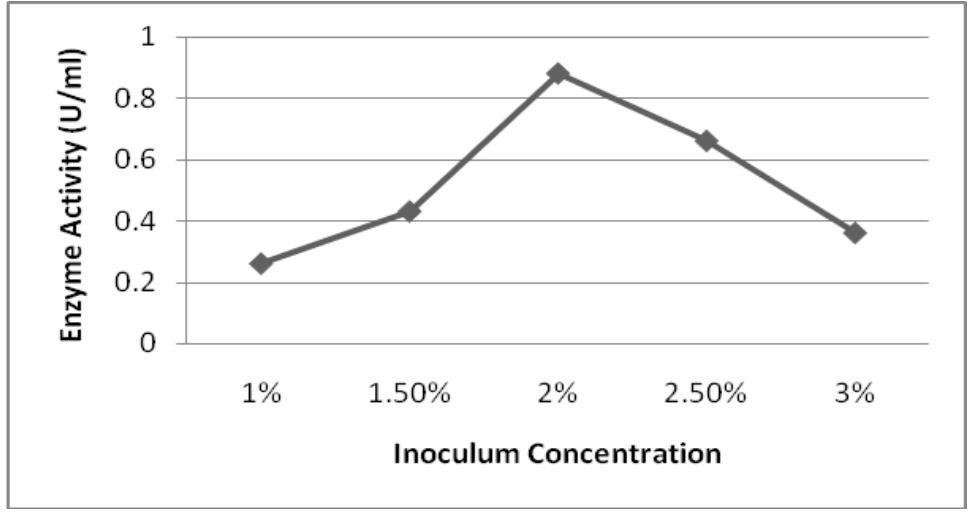

Figure.5 Effect of Nitrogen Source on Enzyme Production by Bacillus subtilis in Enzyme Production Media Containing Waste Paper as Carbon Source

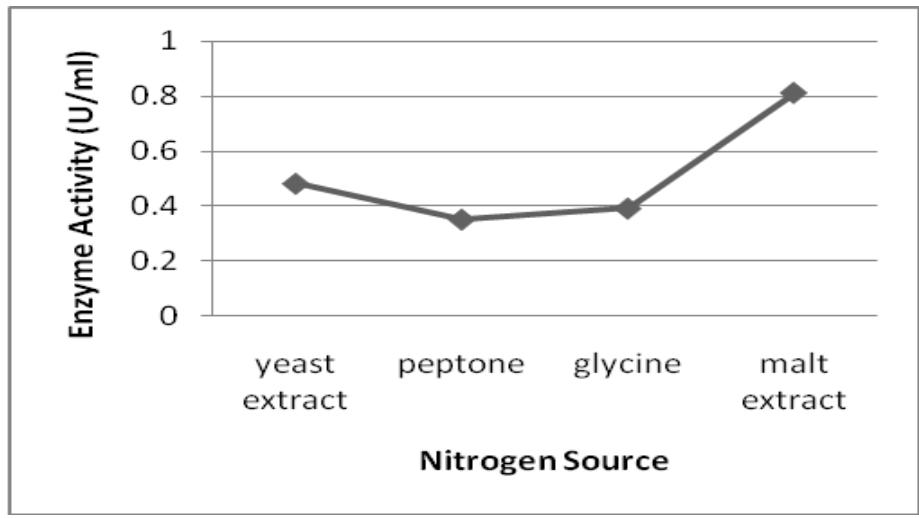




\section{Effect of Nitrogen Source on Cellulase Production}

The Nitrogen source plays an important role in enzyme production. It effect on enzyme production by Bacillus subtilis was studied by supplementing different nitrogen sources into production media. Different nitrogen tested individually at the concentration of $0.5 \%$ nitrogen in production media and is incubated at $45^{\circ} \mathrm{C}$ for $72 \mathrm{hrs}$. The maximum enzyme production observed in media supplemented with malt extract $(0.81 \mathrm{U} / \mathrm{ml})$ as nitrogen source. These data were in accordance with the results of (Ray et al., 2007) who reported that organic nitrogen sources were more suitable for optimizing the cellulase production by Bacillus subtilis, Bacillus circulans than inorganic sources.

In conclusion, several microorganisms capable of converting cellulose into simple carbohydrates had been discovered for decades. However, needs for newly isolated cellulolytic microbes were still remained. In this we have isolated and identified efficient cellulase producing bacteria from cellulose rich environment. The bacterial isolate was characterized based on 16s rRNA sequence and was identified as Bacillus subtilis sub species. The isolate Bacillus subtilis sub species showed a potential to produce cellulase using waste paper as a substrate and its enzyme production efficiency was increased by optimization of cultural conditions and media components. Since pure commercialized cellulose is too expensive to be used as substrate, waste paper may be a good alternative for cellulase production from industrial point of view. Isolation, characterization and optimization of cellulose producing bacteria may provide a good starting point for the discovery of such beneficial enzymes for bioconversion of lignocellulosic waste into ethanol.

\section{References}

Beak, S.C., Know, Y.J. 2007. Optimization of the pretreatment of rice straw hemicellulosic hydrolysates for microbial production of xylitol. Biotechnol. Bioprocess Engi., 12: 404-409.

Bergey, D. 1957. Manual of determinative bacteriology, American - for microbiology, Williams and willkins co. publishers, Baltimore, USA, VII edition.

Bhat, M.K. 2000. Cellulases and related enzymes in biotechnology, Biotechnol. Adv., 18: 355-383.

Brander, J.R., Gillings, M., Nevalainen, K.M.H. 1999. Qualitative assessment of hydrolytic activities in Antarctic micro fungi grown at different temperatures on solid media. World. J. Microbial. Biotechnol., 15: 131132.

Ghoseh, T.K. 1987. Measurement of cellulase activities: Pure Appl. Chem., 59: 257-68.

Huang, T.L., Han, Y.W., Callihan, C.D. 1971. Application of lowry method for determination of cell concentration in fermentation of waste cellulosics. $J$. Ferment. Technol., 49: 574-576.

Immanuel, G., Dhanush, R., Prema, P., Palavesam, A. 2006. Effect of different growth parameter on endoglucanase enzyme activity by bacteria isolated of coir retting effluents of estuarine environment. Int. J. Envsci. Technol., 3: 25-34.

Kim, O.S., Cho, Y.J., Lee, K., Yoon, S.H., Kim, M., Na, H., Park, S.C., Jeon, Y.S., Lee, J.H., Yi, H., Won, S., Chun, J. 2012. Introducing EzTaxone: a prokaryotic $16 \mathrm{~S}$ rRNA Gene sequence database with phylotypes that represent uncultured species. Int. J. Syst. Evol. Microbiol., 62: 716-721. 
Lynd, L.R., Zhang, Y. 2002. Quantitative determination of cellulase concentration as distinct from cell concentration in studies of microbial cellulose utilization, analytical framework and methodological approach. Biotechnol. Bioenergy, 77: 467-475.

Maki, M., Leung, K.T., Qin, W. 2009. The prospects of cellulose producing bacteria for the bioconversion of lignocellulosic biomass, Int. J. Biol. Sci., 5: 500-516.

Miller, G.L. 1959. Use of dinitrosalicyclic acid reagent for determination reducing sugar, Analytical Chem., 31: 426-428.

Nakamura, K., Kappmura, K. 1982. Isolation and identification of crystalline cellulose hydrolyzing bacterium and its enzymatic properties. $J$ Ferment. Technol., 60(4): 343-348.

Perez, J., Munoz-dorado, J., Dela Rubia, J., Marinez, J. 2002. Biodegradation and biological treatments of cellulose, hemicelluloses and lignin an overview. Int. Microbiol., 5: 53-63.

Petre, M., Zarena, G., Adrain, P., Gheorghiu, E. 1999. Biodegradation and bioconversion of cellulose wastes using bacterial and fungal cells and immobilized in radio polymerized hydrogels. Res. Cons. Recy., 27: 309332.

Ray, A.K., Bairagi, A., Ghosh, K.S., Sen, S.K. 2007. Optimization of fermentation conditions for cellulase production by Bacillus subtilis CY 5 and Bacillus circulans JP3 isolated form fish gut, acta ichthylogica ET piscatoria, 37: 47-53.

Song, F.L., Forsberg, C.W., Gibbins, L.N. 1985. Cellulolytic activity of clostridium acetobutylicum. Appl. Env. Microbial., 50: 220-238.

Venkatanagaraju, E., Goli Divakar, T., Rajesh, Akram Ghazi, Arsapourgharashi. 2013. Screening and isolation of cellulose producing bacteria from dump yards of vegetable wastes. World J. Pharm. Pharma. Res., 3(1): 428-435.

Wood, T.M., Bhat. K.M. 1988. Methods of measuring cellulase activities. Method Enzyme, 160: 87-112.

Zhu, S., Wu, Y., Yu, Z., Zhang, X., Li, H., Gao, M. 1964. The effect of microwave irradiation on enzymatic hydrolysis of rice straw. Biores. Technol., 97: 1964-68.

\section{How to cite this article:}

Venkateswar Reddy, K., T.Vijaya Lakshmi, A.Vamshi Krishna Reddy, V.Hima bindu, Lakshmi Narasu, M. 2016. Isolation, Screening, Identification and Optimized Production of Extracellular Cellulase from Bacillus subtilis Sub.sps using Cellulosic Waste as Carbon Source. Int.J.Curr.Microbiol.App.Sci. 5(4): 442-451.doi: http://dx.doi.org/10.20546/ijcmas.2016.504.052 